\section{Godt og grundig om affektive lidelser hos eldre}

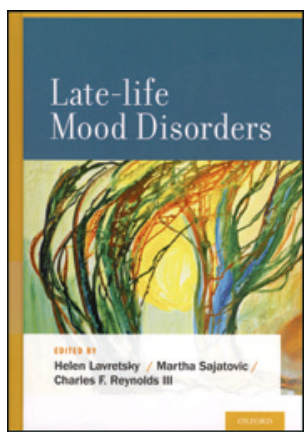

\author{
Helen Lavretsky, Martha Sajatovic, \\ Charles Reynolds III, red. \\ Late-life mood disorders \\ 770 s, tab, ill. Oxford: Oxford University Press, \\ 2013. Pris GBP 95 \\ ISBN 978-0-19-979681-6
}

Affektive lidelser, både depresjoner, angstsykdommer og manier, har vært kjent og beskrevet i litteraturen helt siden vikingtiden. Det har vært forsket mye på disse lidelsene hos yngre voksne og vi begynner nå å få god kjennskap til årsaker til og behandling av dem, men det er først de siste tiår at affektive lidelser hos eldre er blitt viet samme oppmerksomhet. Det er nå en utbredt forståelse for, og enighet om, at affektive lidelser hos eldre har en annen etiologi, andre risikofaktorer og annen prognose enn affektive lidelser hos yngre voksne. De krever derfor en annen tilnærming og behandling.

I denne boken har redaksjonen samlet bidrag fra en imponerende mengde forfattere med god kunnskap om affektive lidelser hos eldre. Redaksjonens intensjon må ha vært å lage en state of the artoppsummering av dagens kunnskap og samtidig beskrive hvor fagfeltet vil bevege seg i tiden fremover. Her er kapitler om etiologi, diagnostisering, sammenheng mellom affektive lidelser og andre nevrologiske sykdommer, biomarkører og behandlingsformer. Mesteparten av kapitlene omhandler depresjon hos eldre, men det er også stoff om angst og manier. Alle emner innenfor affektive lidelser hos eldre blir dekket, inkludert temaer som alternativ behandling og organisering av omsorgstjenester.

Boken er i hardcover, papirkvaliteten er god og teksten er satt med to kolonner, noe som gjør lesingen behagelig. Hvert kapittel er skrevet av en eller flere internasjonalt kjente forfattere. Alle påstander, utsagn og sitater har henvisning til forskning og artikler $i$ internasjonale tidsskrifter, og selv om boken kom ut i år, er det flere referanser til artikler publisert i 2012. Det er liten tvil om at boken er grundig og oppdatert. Den er nok skrevet for det amerikanske markedet, men man finner likevel henvisninger til internasjonal litteratur. Språket er amerikansk-engelsk og lettlest. Med så mange forfattere som bidragsytere er det en fare for gjentakelser i teksten, og selv om det forekommer, er det ikke skjemmende for helhetsinntrykket. Det som derimot trekker ned, er illustrasjonene. De har en overraskende amatørmessig layout og ødelegger for det gode faglige innholdet.

Målgruppen er alle med interesse for affektive lidelser hos eldre, både allmennleger og de som jobber innen psykiatri, nevrologi og sykehjemsmedisin. Selv om boken er stor og innholdsrik, kan den leses som enkeltkapitler eller benyttes som oppslagsverk ved behov for oppdatert kunnskap om enkeltlidelser eller behandlingsanbefalinger. Meg bekjent finnes det ikke noen tilsvarende oppdatert og grundig bok om emnet.

\section{Sverre Bergh}

Alderspsykiatrisk forskningssenter

Sykehuset Innlandet

\section{Interessant om psykiatrisk diagnostikk}

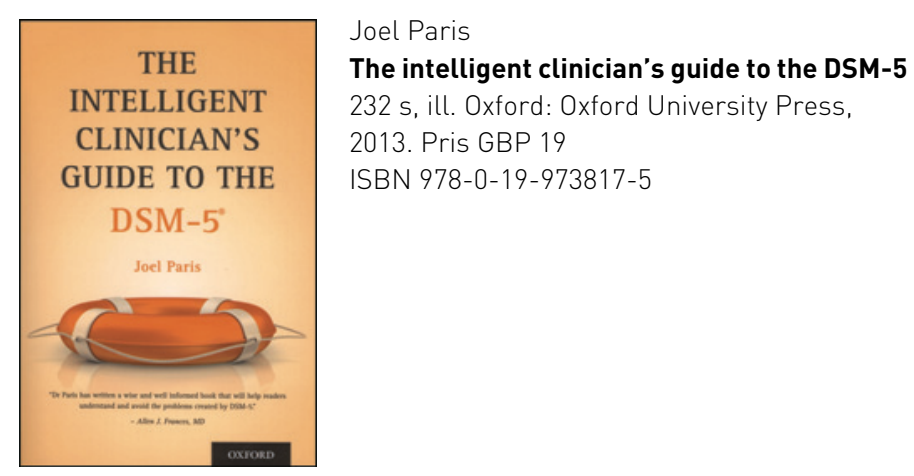

Utgivelsen av den amerikanske diagnosemanualen DSM-V i mai i år har ført til mye diskusjon, ikke bare i psykiatriske fagmiljøer. I denne boken gir Joel Paris en god innføring i problemene knyttet til psykiatrisk diagnostikk generelt, og DSM-V spesielt. Paris, professor i psykiatri i Montreal med mangeårig erfaring fra klinisk arbeid og forskning, er en nestor i faget. Han er også sjefredaktør for The Canadian Journal of Psychiatry.

I Europa brukes ICD-10, men selv om søkelyset er rettet mot DSM-V, er teksten i høyeste grad interessant også for europeiske lesere. Diagnosekategoriene kan ha noe ulik utforming, men argumentasjonen er relevant for begge systemene.

Boken er inndelt i tre hoveddeler. I den første delen tar forfatteren for seg historiske fakta rundt psykiatrisk diagnostikk og definisjon av sykdom, validitet, reliabilitet og klinisk nytte. Han gir interessante innblikk i prosessen rundt utvikling av DSM-V og understreker at DSM-V ikke representerer noen egentlig forskjell fra DSM-IV. Det er bare tatt noen skritt videre når det gjelder å gjøre avgrensningen mellom normalitet og sykdom enda mer utydelig. Dette er Paris' viktigste poeng: Grensene utviskes, noe som fører til sykeliggjøring og overbehandling. Dette understrekes i den andre delen, der han beskriver diagnosegrupper nærmere. Den tredje og siste delen er en oppsummering.

Teksten fremstår som et velskrevet og velbegrunnet debattinnlegg. Forfatteren skriver underholdende og engasjert, selv om han gjentar hovedpoengene litt for ofte. Enkelte er sikkert uenige i argumentene når det gjelder for eksempel skepsis til tidlig diagnostikk av psykoser, inflasjon i bruk av diagnosen bipolar lidelse eller mangelfull og dårlig fundert avgrensning av depresjon, angst eller $\mathrm{AD} / \mathrm{HD}$, men argumentasjonen er overbevisende og basert på omfattende kunnskap fra ulike forskningsfelt. Forfatterens kritikk mot DSM-V (og ICD-10) er grunnleggende. På tross av dette mener han at en ufullstendig klassifisering er bedre enn ingenting. Hovedbudskapet er at både klinikere og forskere må vise stor grad av ydmykhet og pragmatisme når det gjelder diagnoser, stole på eget klinisk skjønn og være skeptiske til etablerte sannheter.

Boken er nok mest egnet for klinikere og forskere med over middels interesse for temaet, og mindre som håndbok for ferske klinikere. Likevel kan det være mye interessant og nyttig å hente, både $\mathrm{i}$ introduksjonskapitlet og $\mathrm{i}$ beskrivelsen av de ulike diagnosegruppene. De som ønsker en kort oppsummering, kan lese den siste delen, med den talende tittelen $A$ guide for the perplexed. Her gis et overblikk over hovedmomenter i en ikke spesielt enkel, men viktig debatt.

Anne Høye

Allmenpsykiatrisk klinikk

Universitetssykehuset Nord-Norge 